Agro-Science Journal of Tropical Agriculture, Food, Environment and Extension Volume 20 Number 3 (July 2021) pp. 49 - 52

ISSN 1119-7455

\title{
CONTRIBUTION OF SNAIL PRODUCTION TO INCOME STATUS OF SNAIL FARMERS IN EDO SOUTH, EDO STATE, NIGERIA
}

\author{
"Ahmadu J., Ida-Ogbomo E.O. and Oyoboh D.E. \\ Department of Agricultural Economics \& Extension Services, University of Benin, Benin, Nigeria \\ ${ }^{*}$ Corresponding author email: joseph.ahmadu@uniben.edu
}

\begin{abstract}
This study examined the contribution of snail production to the income status of snail farmers in Edo South Senatorial District, Edo State, Nigeria. The specific objectives of the study were to describe the socioeconomic characteristics of snail producers, estimate the costs and returns of snail production in the study area, examine the effect of snail production on income of snail farmers and identify the constraints to the production of snail in the study area. A two-stage sampling procedure comprising purposive and snowballing sampling techniques was employed to select 108 respondents for the study. However, 100 respondents provided useful information that was used for the analysis. Data were collected using structured questionnaire. Analysis of data was done using descriptive statistics and budgetary techniques and t-test. The results indicated that the majority of the respondents were females (61\%) with average age of 38 years. Most of them were married (81\%) with average household size of five persons. They had average of eight years experience in snail rearing and most of them (88\%) were literate. The results further showed that the business of snail production in the study area was profitable with gross margin, net profit and return on investment of \$359,455.00, 339, 533.00 and 2.04 per annum, respectively. Without income from this business, the snail farmers had average annual income of $\$ 1,377,519.00$ from other sources of livelihood. With the addition of income from snail production, their average annual income increased to $\$ 1,717,052.00$, representing $20 \%$ increase. This increase was significant at $p<0.05$ (t-ratio $=5.02)$. Thus, snail production had made significant contribution to improving the income of the snail producers. It was recommended that the unemployed youths should go into the business of snail production in order to improve their income status.
\end{abstract}

Key words: effect, snail production, income, snail farmers, Nigeria

\section{INTRODUCTION}

The dwindling economy and widespread poverty in Nigeria and most developing countries of the world (Ahmadu and Alufohai, 2011; National Bureau of Statistics, 2012) call for a search for a business enterprise and a source of income whose investment capital in terms of finance, human resources, time and space is relatively low and affordable. Snail production fits perfectly into these requirements because the capital outlay for snail production is affordable, relatively cheap to start and manage when measured against its productivity, returns and other livestock (Ahmadu and Ojogho, 2012). This assertion confirmed the observation by Goodman (2008) that the amount of capital required for the establishment of a snailery is appreciably small and the practice requires little labour with no strenuous physical exertion. Furthermore, Nigeria is endowed with various species of snail that farmers can rear. Some of these species include Achatina achatina, Archachatina marginata, Achatina fulica, Limicolaria species, Thapsia species and Lanistes varicus (Odunaiya, 1995; Okon et al., 2012).
According to Okon and Ibom (2010), microlivestock (such as snail, grasscutter, rabbit, guinea pigs, quail and African giant rat, etc.) generally have inherent potentials to meet the meat protein and dietary needs of the populace. Specifically, snail meat is rich in protein, iron, calcium and phosphorus, but low in sodium, fat and cholesterol, and also contains almost all the amino acids needed by man (Awesu, 1990; Adeyeye, 1996; Akinnusi, 2002; Ejidike, 2002). Apart from the nutritional importance of snail to health, it has the ability to be reared under various conditions and snails have high rate of reproduction. These could be the reasons why Okon and Ibom (2010) stated that the commercial production of snails can be seen as an honest approach towards realizing improved meat protein intake in Nigeria. There is, therefore, the need to intensify the integration of commercial snail production into animal agricultural system in order to promote healthy dieting and to generate income among practitioners in the snail industry. The vital question of interest here is, can income from the commercial production of snails contribute significantly to the income of snail farmers?

Please cite as: Ahmadu J., Ida-Ogbomo E.O. and Oyoboh D.E. (2021). Contribution of snail production to income status of snail farmers in Edo South, Edo State, Nigeria. Agro-Science, 20 (3), 49-52. DOI: https://dx.doi.org/10.4314/as.v20i3.7 
This study was designed to examine the contribution of snail production to the income status of snail farmers in Edo South, Edo State, Nigeria. The specific objectives of the study were to (i) describe the socio-economic characteristics of snail producers in the study area, (ii) estimate the costs and returns of snail production, (iii) examine the effect of snail production on income of snail farmers, and (jv) identify the constraints to the production of snail in the study area.

\section{METHODOLOGY}

\section{Study Area}

The study area is Edo South, Edo State, Nigeria. Edo south is in the southern part of Edo state which is located in the tropical rainforest belt between latitudes $5^{\circ} 49^{\prime} \mathrm{N}$ and $6^{\circ} 50^{\prime} \mathrm{N}$ of the equator and longitudes $5^{\circ} \mathrm{E}$ and $6^{\circ} 10^{\prime} \mathrm{E}$ of prime meridian (Osawaru and Daniel-Ogbe, 2012). The mean annual rainfall in the area is high (about $250 \mathrm{~cm}$ ) and relative humidity is also high. The average temperature is estimated at $25^{\circ} \mathrm{C}$ in the rainy season and $28^{\circ} \mathrm{C}$ in the dry season (Benin Kingdom/Edo State Tourism, 2019). These conditions are favourable for snail rearing.

Edo South has a projected population of 2, 208, 700 people as at 2016 (City Population, 2020) comprises seven local government areas (LGAs) out of the 18 LGAs of Edo state. These include; Egor, Ikpoba-Okha, Oredo, Orhionmwon, Ovia north east, Ovia south-west and Uhunmwonde. Agriculture is the major occupation of the inhabitants of the area. Both crop and livestock productions are carried out. Some of the main livestock reared in the area include; cattle, sheep, goat, pigs, poultry and micro-livestock such as rabbits, snails, among others.

\section{Sampling Procedure and Data Collection}

A two-stage sampling procedure was employed to select the respondents for the study. First, four LGAs including Egor, Ikpoba-Okha, Ovia-North East and Ovia South-West with high snail production were purposively selected from the seven LGAs of the study area. The second stage was the application of snowballing sampling technique to locate the snail farmers in the study area. A total of 108 snail farmers comprising 26, 26, 36 and 16 farmers identified in Egor, Ikpoba-Okha, Ovia North East and Ovia South West LGAs, respectively were interviewed for the study. However, 100 respondents provided useful information that was used for analysis. There were few farmers identified snail farmers for the study, hence the use of all of them which still represented a small sample size.

Primary data for the study were collected using structured questionnaire. Data were collected on the socio-economic characteristics of the farmers, quantities of inputs and output of snail production as well as their unit prices, and the constraints faced by the farmers in the business.

\section{Data Analysis}

Data analysis was done using descriptive statistics (means, frequency counts and percentages), budgetary techniques and information from Likert-type scale.

\section{Budgetary techniques}

The budgetary techniques used include gross margin and net profit analyses as well as return on investment. The gross margin and net profit analyses were used to determine the profitability of the snail production business. The net income from the snail production business served as a basis for comparison with income from other productive activities. The gross margin as used by Okoror and Ahmadu (2017) is given as:

$$
\mathrm{GM}=\mathrm{TR}-\mathrm{TVC}
$$

where GM is gross margin ( $\mathrm{A}$ ), TR is total revenue $(\mathrm{N})$, and TVC is total variable cost $(\mathrm{N})$. The net profit $(\pi)$ is expressed as:

$$
\Pi=\mathrm{GM}-\mathrm{TFC}
$$

where TFC is total fixed cost ( $)$. The fixed costs included rent on land, market tax and depreciation of snail pen, water tank, plastic buckets, wheelbarrow, watering can, water and feeding troughs and small weighing scale. Return on investment (ROI) is given as:

$$
\mathrm{ROI}=\frac{\pi}{\mathrm{TC}}
$$

where TC is total cost (

\section{T-test}

The t-statistics was used to test the significant difference between income from snail production and income from other sources of livelihood. The ttest adapted from Olayemi (1998) is given as:

$\mathrm{t}=\frac{\overline{\mathrm{X}}_{2}-\overline{\mathrm{X}}_{1}}{\frac{\mathrm{S}_{2}+\mathrm{S}_{1}}{\sqrt{\mathrm{N}}}}$

where $\bar{X}_{2}$ is mean of income from other sources of livelihood; $\bar{X}_{1}$ is mean of income from snail production; $S_{2}$ and $S_{1}$ represent standard deviation of farmer's income from other sources of livelihood and income from snail production, respectively; and $\mathrm{N}$ is sample size.

\section{RESULTS AND DISCUSSION}

Socio-Economic Characteristics of Snail Farmers Table 1 shows the socio-economic characteristics of the snail producers in the study area. The results showed that majority $(61 \%)$ of the respondents were females, indicating that rearing of snail in the study area was dominated by females. This might be due to the fact that the business of snail rearing is not labour intensive and required low capital investment (Ahmadu and Ojogho, 2012). The snail producers had average age of 38 years with $58 \%$ of them falling within the age bracket of 31-50 years. This means that the farmers were mostly youths, 
indicating a good prospect for the snailery subsector in Nigeria. Most of the farmers were married $(81 \%)$ with average household size of five persons, implying that they would give attention to their businesses in order to carter for their families, ceteris paribus. Besides, their family members might also contribute to the business through the provision of family labour, all things being equal. The results further showed that the farmers had experience in snail rearing ranging from 1-32 years with the average of eight years. This means that they were quite experienced in the business. Majority of these snail farmers $(88 \%)$ were literate. Their years of experience and education might play a major role in accessing useful information concerning their production practices that would enable them to be efficient in managing the business which could lead to increased productivity and income.

Table 1: Socio-economic characteristics of the farmers

\begin{tabular}{|c|c|c|}
\hline Category & Frequency (100) & Percentage (100) \\
\hline \multicolumn{3}{|l|}{$\operatorname{Sex}$} \\
\hline Male & 39 & 39.00 \\
\hline Female & 61 & 61.00 \\
\hline Age $(<31)$ & 29 & 29.00 \\
\hline Age (31-50) & 58 & 58.00 \\
\hline Age $(>50)$ & 13 & 13.00 \\
\hline Minimum & 23 & \\
\hline Maximum & 59 & \\
\hline Mean & 38 & \\
\hline \multicolumn{3}{|l|}{ Marital status } \\
\hline Single & 19 & 19.00 \\
\hline Married & 81 & 81.00 \\
\hline \multicolumn{3}{|l|}{ Household size } \\
\hline$<6$ & 48 & 48.00 \\
\hline $6-10$ & 45 & 45.00 \\
\hline $11-15$ & 6 & 6.00 \\
\hline$>15$ & 1 & 1.00 \\
\hline Minimum & 1 & \\
\hline Maximum & 20 & \\
\hline Mean & 5 & \\
\hline \multicolumn{3}{|c|}{ Snail production experience } \\
\hline $1-10$ & 73 & 73.00 \\
\hline $11-20$ & 21 & 21.00 \\
\hline $21-30$ & 5 & 5.00 \\
\hline $31-40$ & 1 & 1.00 \\
\hline Minimum & 1 & \\
\hline Maximum & 32 & \\
\hline Mean & 8 & \\
\hline \multicolumn{3}{|l|}{ Educational level } \\
\hline No formal education & 12 & 12.00 \\
\hline Primary education & 14 & 14.00 \\
\hline Secondary education & 45 & 45.00 \\
\hline Tertiary education & 29 & 29.00 \\
\hline
\end{tabular}

Source: Field Survey, 2015

\section{Costs and Returns of Snail Production}

The results of the average costs and returns of snail production presented in Table 2 show that the business of snail production in the study area was profitable. This is evidenced by the results of the gross margin, net profit and return on investment ( $\$ 359,455.00, \$ 339,533.00$ and 2.04 per annum, respectively). The return on investment indicated that every naira invested in the business yielded a net income of 2.04. The net profit represents the income generated by the snail rearers from the business in a year. Previous studies have shown that snail production is profitable. Baba and Adeleke (2006) reported a net return of $\$ 40$ per snail and return on investment of $\$ 1.39$; Ahmadu and Ojogho (2012) reported a net profit per snail of $\$ 63.44$.

\section{Effect of Snail Production on Farmers' Income}

Table 3 shows the average annual income of the farmers from snail production and other sources of livelihood. Without income from snail production, the snail rearers had average annual income from other sources of livelihood of $1,377,519.00$. With the addition of income from snail production, the average annual income of the farmers increased to $\$ 1,717,052.00$, representing about 20\% increase. This increase was significant at $1 \%$ probability level as indicated by the result of the $t$-statistics (5.02). This shows that snail production had made a significant contribution to improving the income status of the farmers. This result corroborates the assertion of Ahmadu and Ojogho (2012) that there is high economic potential in snail production industry for uplifting the living standard of the rural poor.

Table 2: Average costs and returns of snail production per annum

\begin{tabular}{ll} 
Category & $\begin{array}{c}\text { Mean quantity } \\
\text { (number) /value ( })\end{array}$ \\
\hline Returns & \\
Output of snails produced (number) & 1807 \\
Average selling price per snail (N) & 280.00 \\
Total revenue ( & $505,960.00$ \\
Variable cost (N) & \\
Cost of purchase (1858 baby snails) & $129,663.00$ \\
Labour cost & $13,994.00$ \\
Transportation cost & 759.00 \\
Cost of feed & $1,822.00$ \\
Medication & 240.00 \\
Cost of water & 27.00 \\
Total variable cost & $146,505.00$ \\
Total fixed cost & $19,922.00$ \\
(depreciation, rent and market tax) & $166,427.00$ \\
Total cost & $359,455.00$ \\
Gross margin & $339,533.00$ \\
Net profit $(\pi)$ & 2.04 \\
Return on investment &
\end{tabular}

Source: Field Survey, 2015 
Table 3: Average annual income from snail production and other sources of livelihood of the farmers

\begin{tabular}{|c|c|c|c|}
\hline \multicolumn{2}{|l|}{ Category } & \multirow{2}{*}{$\begin{array}{c}\text { Mean annual income }(\mathbb{N}) \\
339,533.00\end{array}$} & \multirow{2}{*}{$\begin{array}{c}\text { Percentage of total (\%) } \\
19.77\end{array}$} \\
\hline Income from snail production & & & \\
\hline \multirow{7}{*}{ Income from other sources of livelihood } & Crop production & $217,354.00$ & 12.66 \\
\hline & Livestock production (snailery exclusive) & $273,750.00$ & 15.94 \\
\hline & Marketing (trading) & $294,832.00$ & 17.17 \\
\hline & Civil service & $380,750.00$ & 22.18 \\
\hline & Others (tailoring, hair dressing) & $210,833.00$ & 12.28 \\
\hline & Total income & $1,377,519.00$ & 80.23 \\
\hline & Total annual income & $1,717,052.00$ & 100.00 \\
\hline \multicolumn{3}{|c|}{$t$-ratio of significant difference between income from snail production and income from other sources of livelihood } & $5.02 *$ \\
\hline
\end{tabular}

Table 4: Perceived benefits derived from snail production

\begin{tabular}{|c|c|c|}
\hline Perceived benefit & & Mean \\
\hline Source of animal protein & & 3.77 \\
\hline Increased income & & 3.64 \\
\hline Source of employment & & 3.46 \\
\hline Feed family with ease & & 3.34 \\
\hline Improved standard of living & & 3.20 \\
\hline Source of waste conversion & & 2.97 \\
\hline \multicolumn{3}{|c|}{ Source: Field Survey, 2015; *Mean $\geq 2.50$ is significant } \\
\hline \multicolumn{3}{|c|}{ Table 5: Constraints faced in snail production } \\
\hline Constraints & Frequency & Percentage \\
\hline Diseases and parasites infestation & 9 & 9.00 \\
\hline Insect pests attack & 44 & 44.00 \\
\hline Pilfering & 30 & 30.00 \\
\hline Feed poisoning & 5 & 5.00 \\
\hline Inadequate technical knowledge & 2 & 2.00 \\
\hline High rate of mortality & 10 & 10,00 \\
\hline Total & 100 & 100.00 \\
\hline
\end{tabular}

Source: Field Survey, 2015

Perceived Benefits from Snail Production

On the perceived benefits derived from the business of snail production (Table 4), the snail farming had made significant contributions to the snail farmers as a source of animal protein, extra income, and employment, and enabled them to feed their families with ease. Other benefits include improved standard of living and source of waste conversion.

\section{Constraints of Snail Production}

The major constraints in snail farming were insect pests attack (44\%) and pilfering (30\%) (Table 5). This result is in line with Ejidike (2002) who reported that a number of organisms pose danger to snails. These include frog, toad, millipedes, centipedes, lizard, cockroaches, soldier ants and termites.

\section{CONCLUSION \& RECOMMENDATION}

The study has established that snail production was a profitable business venture which had made significant contribution to improving the income status of the snail producers. Evidently, the business was profitable with gross margin, net profit and return on investment of $\$ 359,455.00, \$ 339,533.00$ and 2.04 per annum respectively. Thus, the income of the snail farmers significantly $(p<0.01)$ increased by $20 \%$. Despite this positive contribution, the enterprise was faced with some constraints, mainly insect pests attack and pilfering. If the farmers access and rear the breed of snails that are resistant to insect pests and properly monitor their business to avert pilfering, the income generated from the business will increase.

Based on the findings of this study, it is hereby recommended that the unemployed youths should go into the business of snail production.

\section{REFERENCES}

Adeyeye E.I. (1996). Waste yield, proximate and mineral composition of three different types of land snail found in Nigeria. Int. J. Food Sci. Nutr., 47 (2), 111-116

Ahmadu J. and Alufohai G.O. (2011). Effect of yam production on poverty alleviation of famers in Ika area of Delta state, Nigeria. Int. J. Agric. Econ. Ext. Serv., 1 (1), 148-160

Ahmadu J. and Ojogho O. (2012). Economics of snail production in Edo State, Nigeria. Int. J. Agric. Sci., 4 (5), 233-237

Akinnusi O. (2002). Introduction to Snails and Snail Farming. Triolas Exquisite Ventures, Abeokuta, Nigeria

Awesu M.O. (1990). The Biology and Management of the African Giant Land Snail (A. marginata). M.Phil. Thesis, University of Ibadan, Ibadan, Nigeria

Baba K.M. and Adeleke M.T. (2006). Profitability of snail production in Osun State, Nigeria. J. Agric. Food Sci., 4, 147-155

Benin Kingdom/Edo State Tourism (2019). Benin kingdom/Edo state weather. Retrieved from: https://www.edoworld.net/Edotourismweather.html

City Population (2020). The population of states and local government areas of Nigeria, adminitrative division. Retrieved from: www.citypopulation.de

Ejidike B.N. (2002). Snail rearing practices in southern Nigeria. $27^{\text {th }}$ Proc. Annual Conference of Nigerian Society for Animal Production (NSAP), Akure, Nigeria. March 17-21.pp. 307-308

Goodman A.K. (2008). Giant African land snails. http:// www.geocities.com/heartland/valley/6210/index1.htm

National Bureau of Statistics (2012). The Nigeria poverty profile 2010 report. Press Briefing by the StatisticianGeneral of the Federation/Chief Executive Officer, NBS Held at the Conference Room, $5^{\text {th }}$ Floor, NBS Headquarters, Abuja on $13^{\text {th }}$ February. Retrieved from: www.proshareng.com/reports/Achives

Odunaiya O. (1995). The utilization of snails in Nigeria. M.Sc. Thesis, University of Ibadan, Ibadan, Nigeria

Okon B. and Ibom L.A. (2010). Commercialization of snail production in Nigeria: Potentials, viabilities and challenges. J. Appl. Sci., 13 (2), 9139-9158

Okon B., Ibom L.A., Williams M.E. and Ekong N.B. (2012). Effects of breed on reproductive efficiency of two most popular snails (Archachatina marginata $\mathrm{S}$. and Achatina achatina L.) in Nigeria. J. Agric. Sci, 4 (8), 236-245. DOI: 10.5539/jas.v4n8p236

Okoror O.T. and Ahmadu J. (2017). Maize cob losses and their effects on the poverty status of maize farmers in Edo state, Nigeria. Agro-Science, 16 (1), 31-35

Olayemi J.K. (1998). Elements of Applied Econometrics. Elshaddai Global Ventures Limited, Ibadan, Nigeria. pp. 65-80

Osawaru M.E. and Daniel-Ogbe F.M. (2012). Crop diversity and utilization pattern in home garden from southern Edo state, Nigeria. Afr. Sci., 13 (1), 23-39 